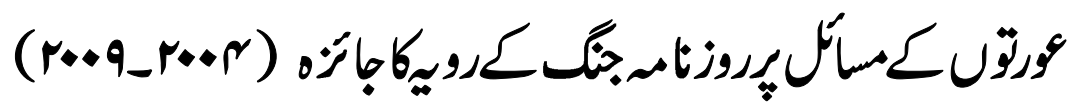

\author{
رفيحتtن \\ ثعبرابلانعامه، جامدكرايق
}

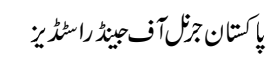

\section{تلخيص المقاله}

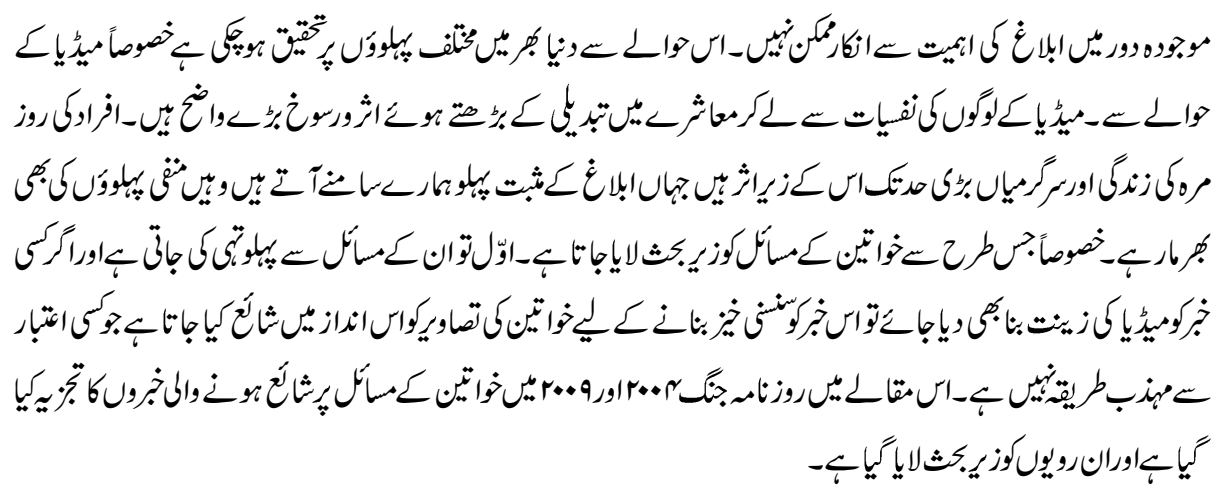

\section{Abstract}

Importance of media can not be neglected in this era. Different researches on different aspects of media are conducted around the globe. Media can change the thinking of people and can change the situation in the society. Daily routine of a person is under the influance of media. Along positive effects of media negative impact of media are also clear specially in reporting of issues related to women. Firstly their problem are marginalized and if reported they are sensationalized portraing picture of women. In this article news and reports related to women issues reported in Daily Jang July 2004 and 2009 are analyzed.

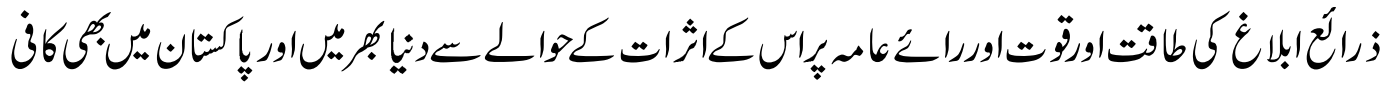

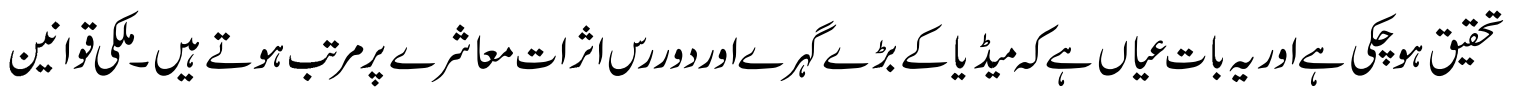

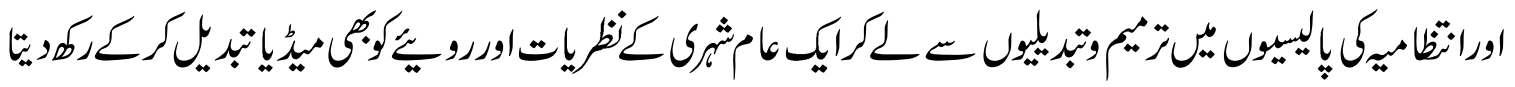




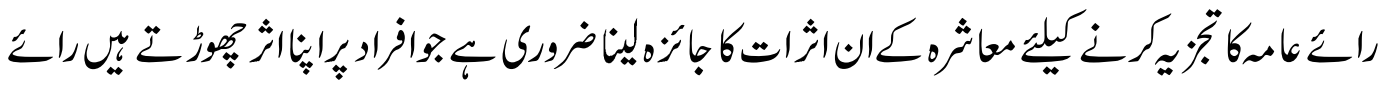

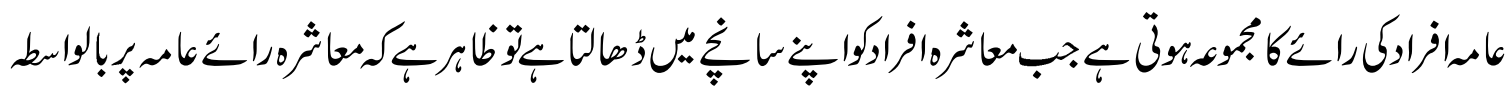

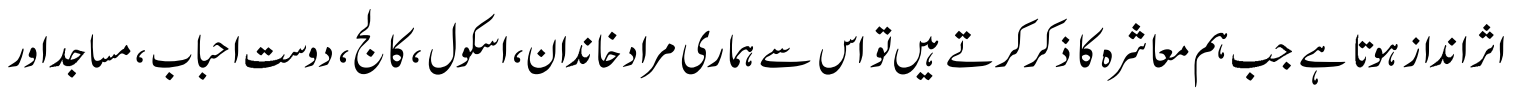

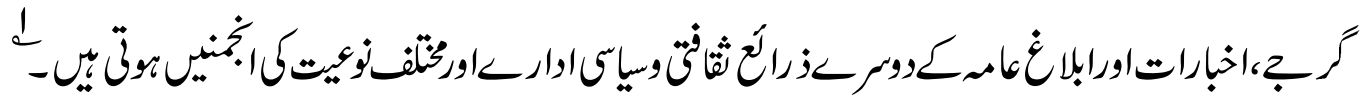

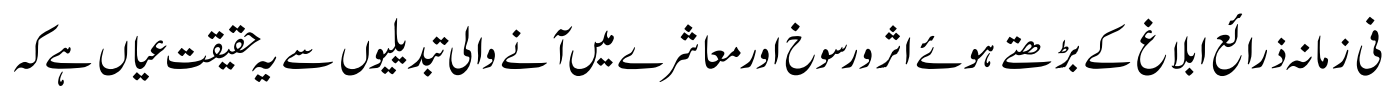

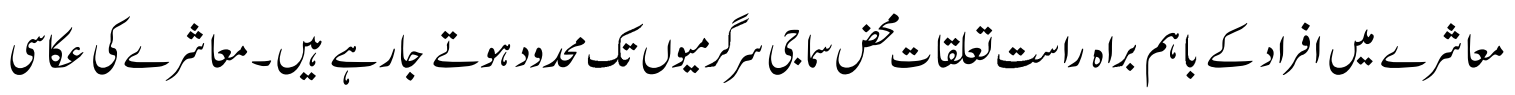

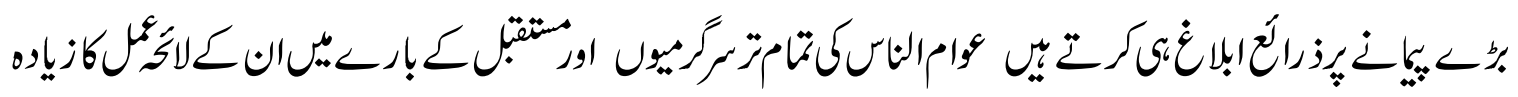

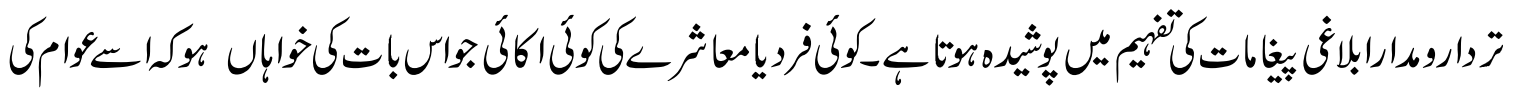

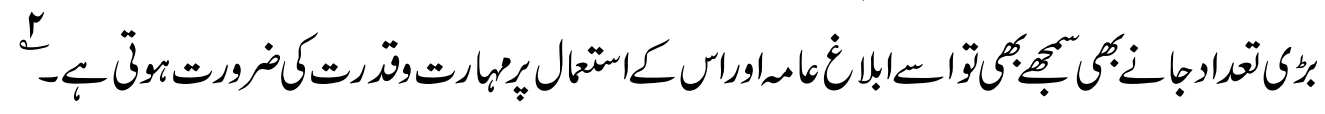

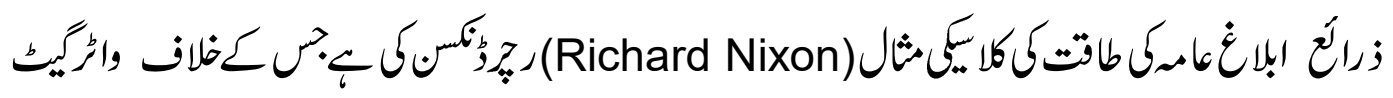

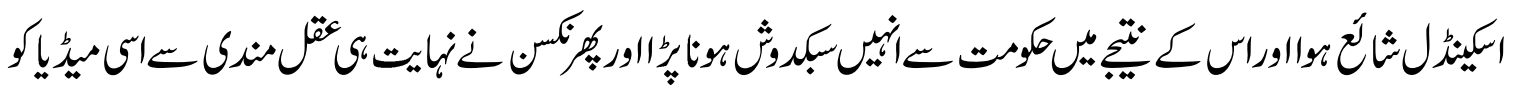

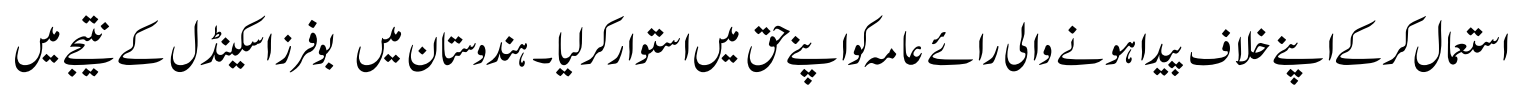

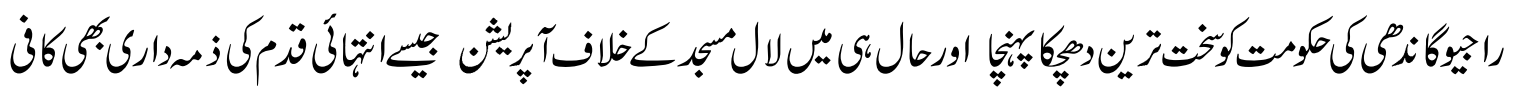

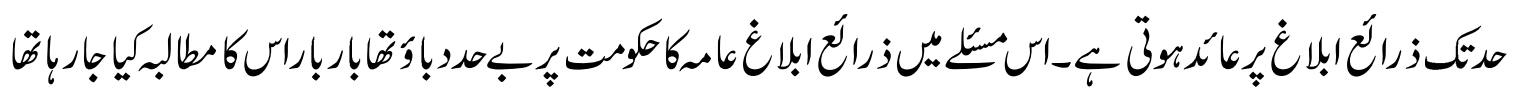

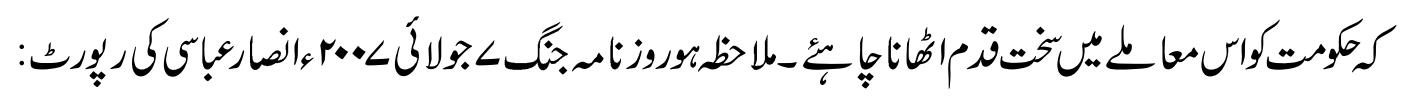

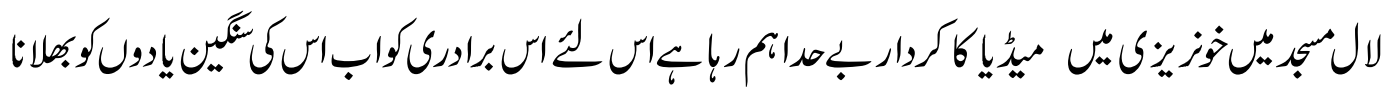

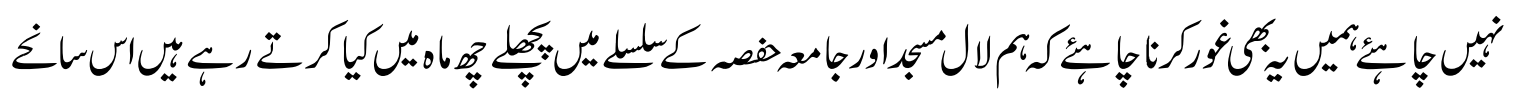

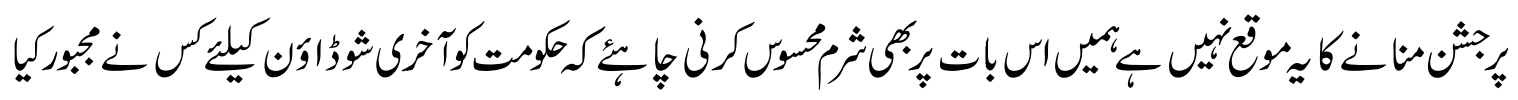

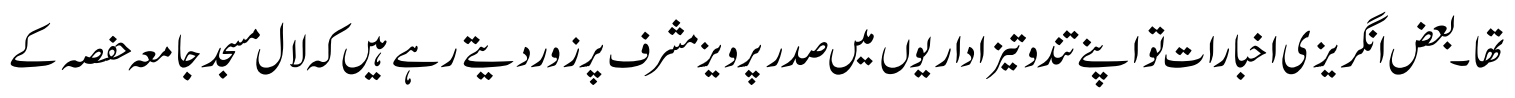

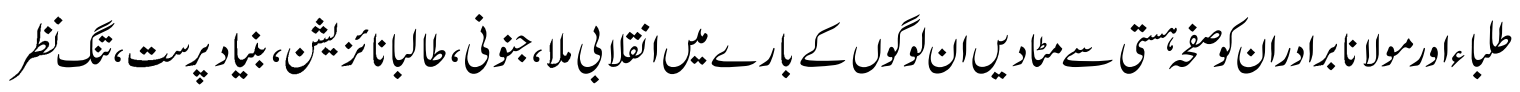


رن

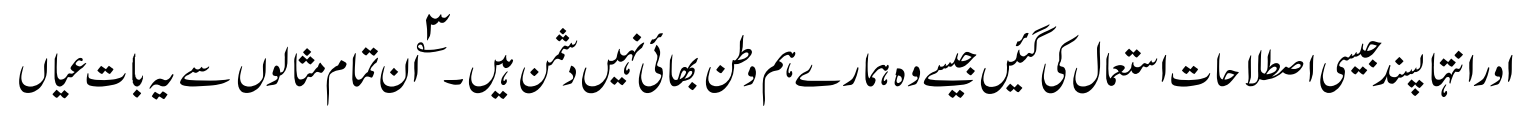

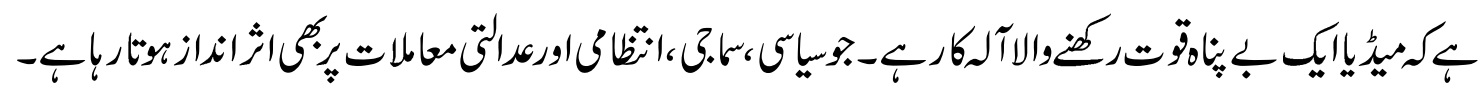

متلمزيختيقت

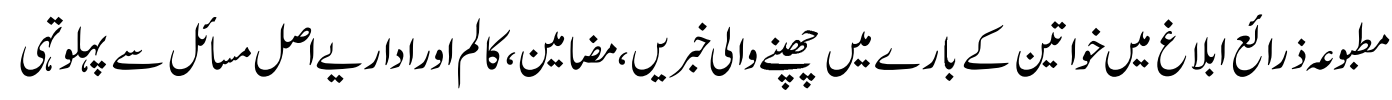

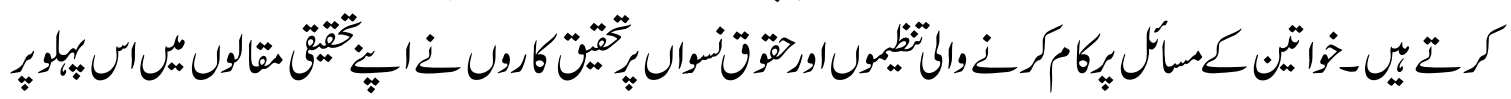

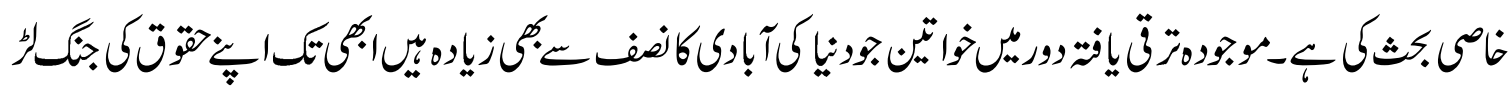

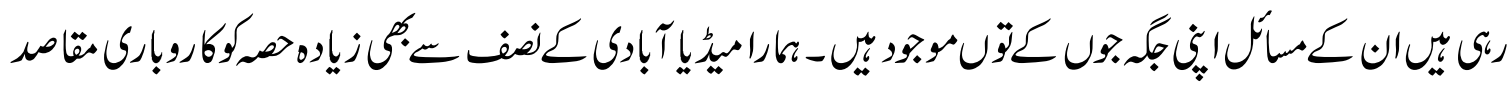

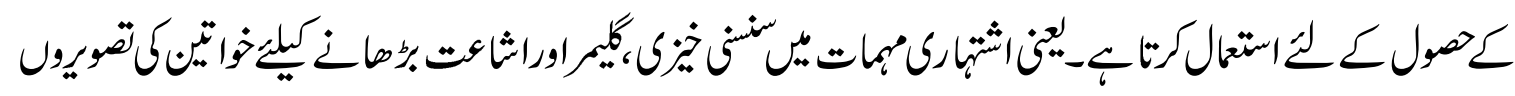

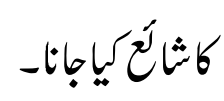

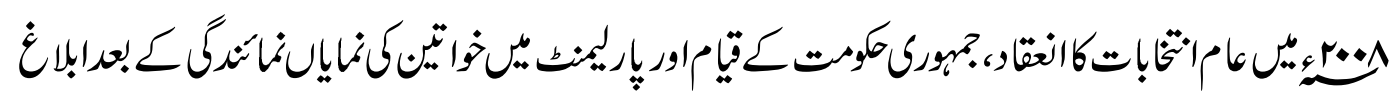

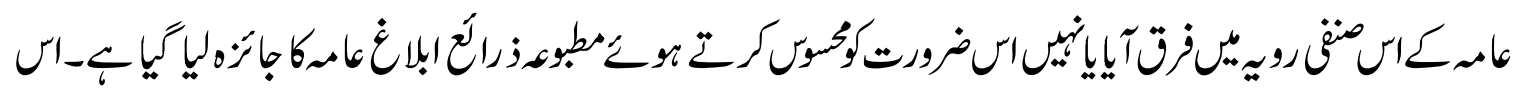

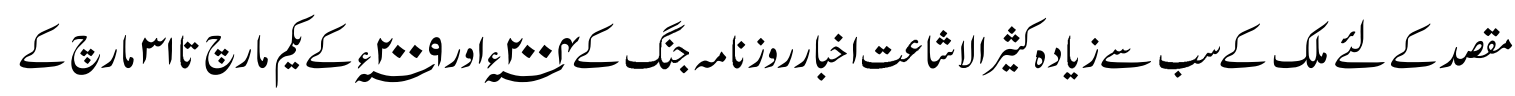

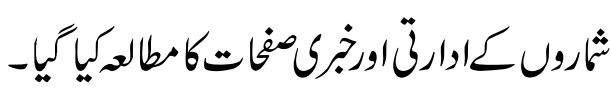

مر لِيّكرر

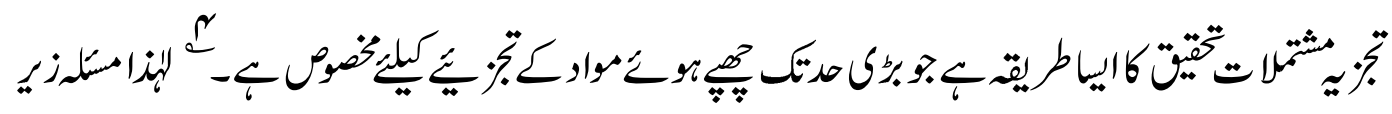

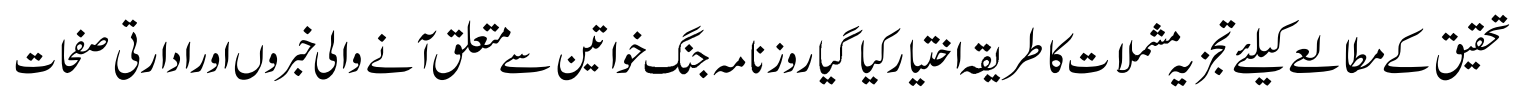

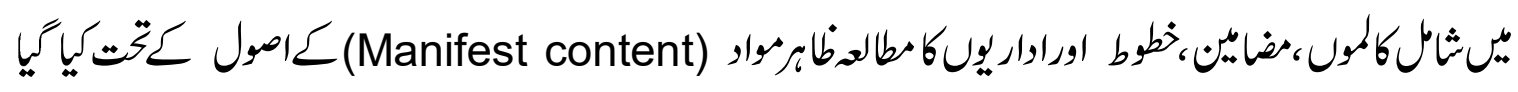

$-4$

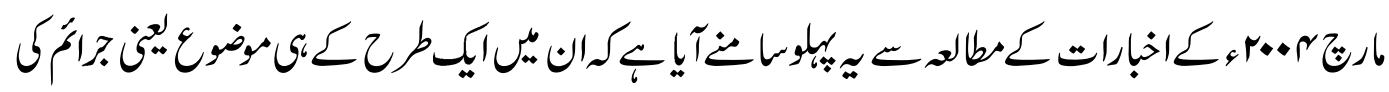




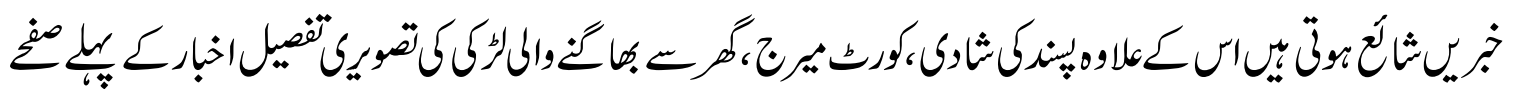

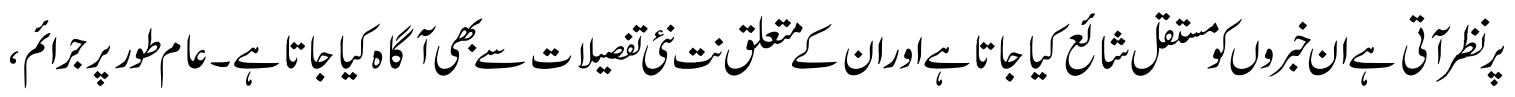

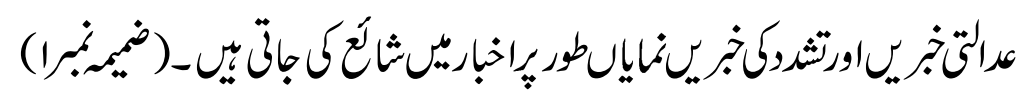

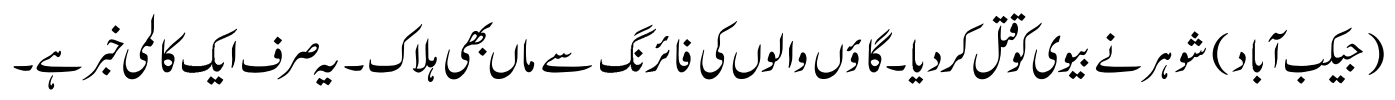

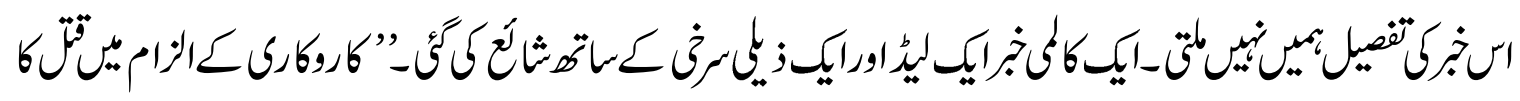

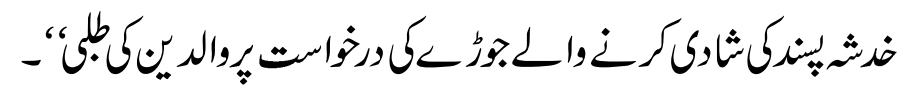

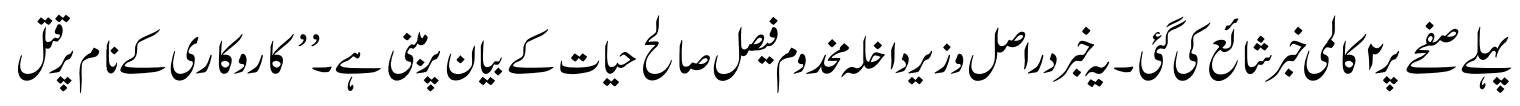

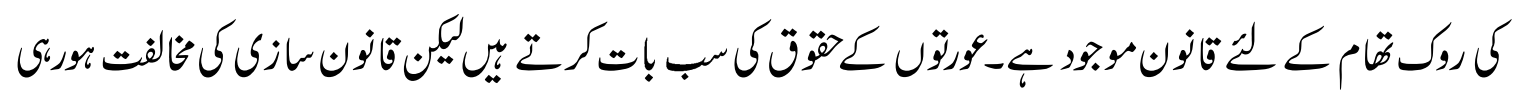

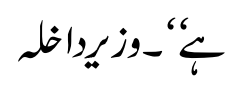

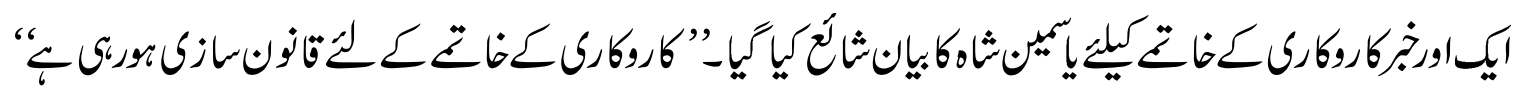
إسميمنثاه

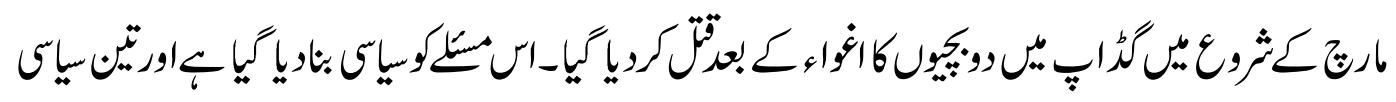

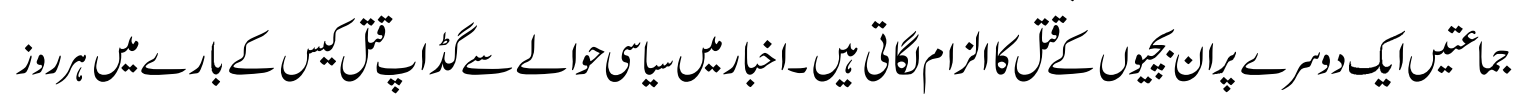

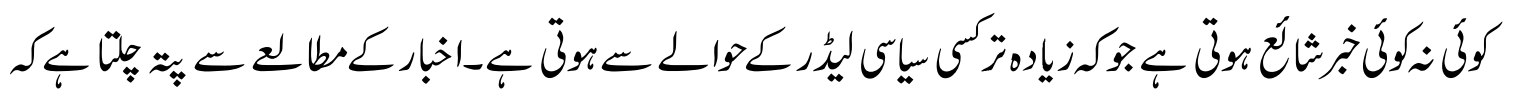

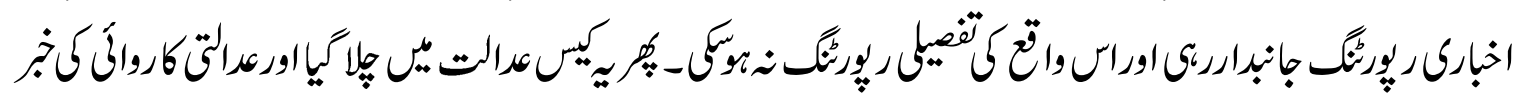

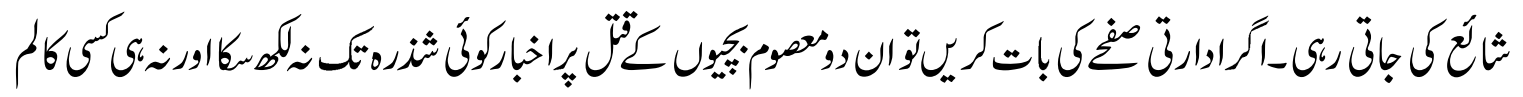

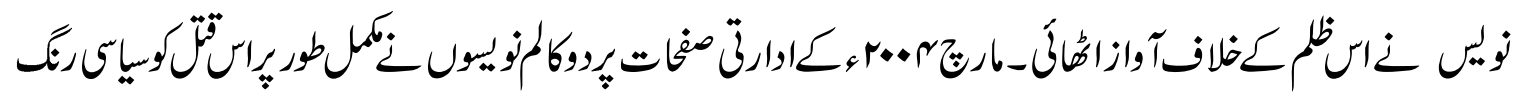

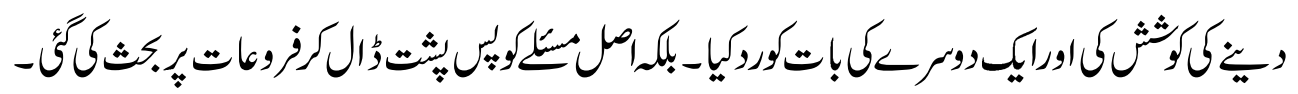

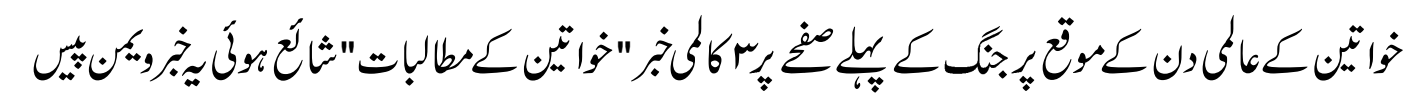

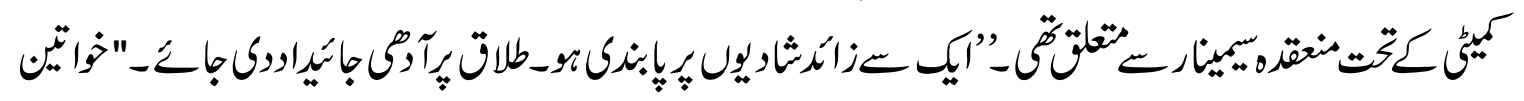

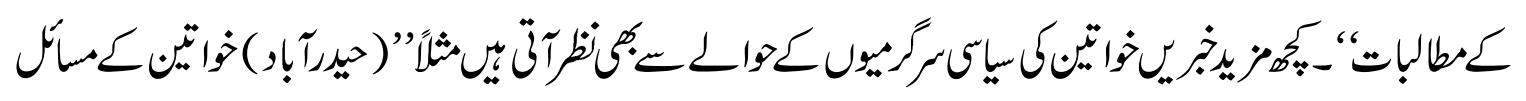




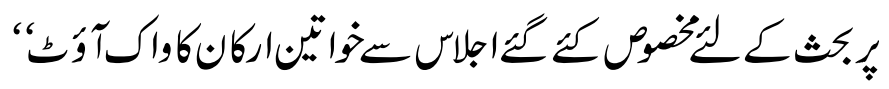

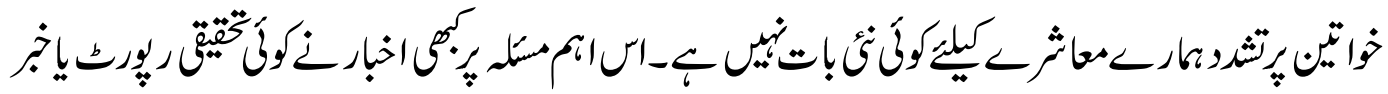

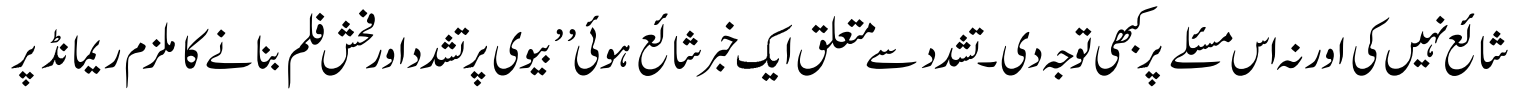

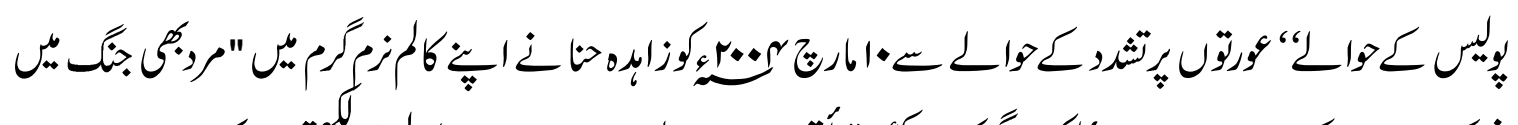

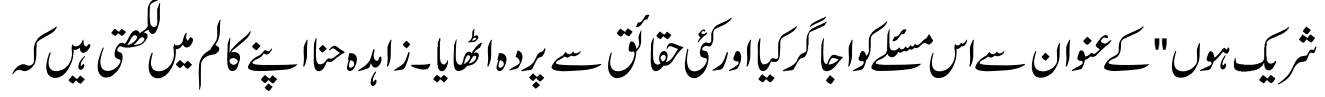

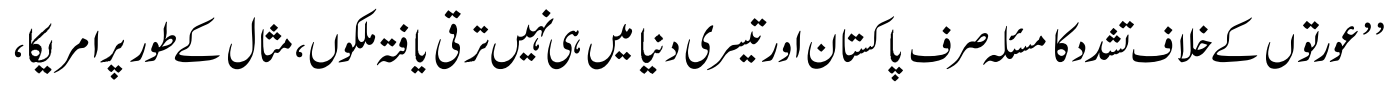

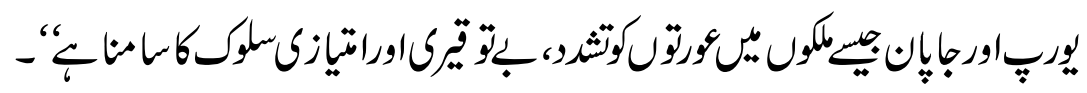

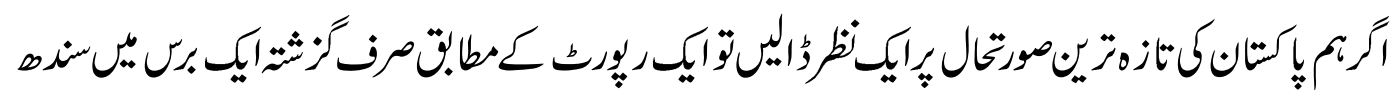

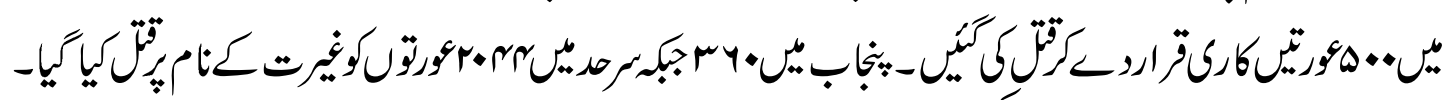

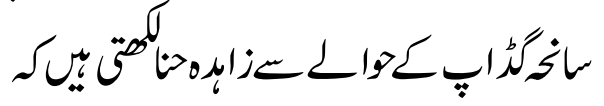

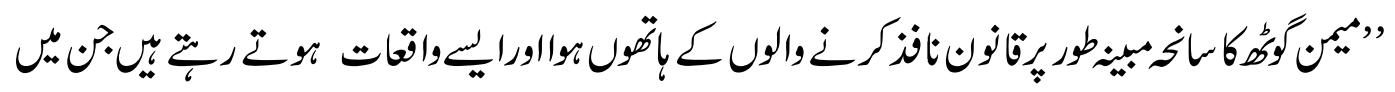

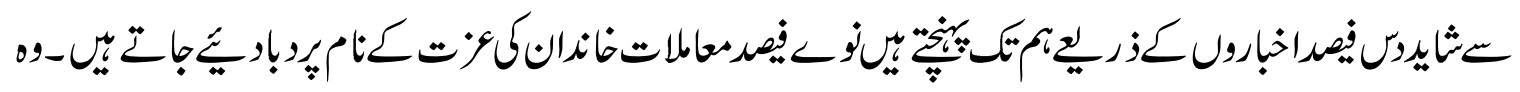

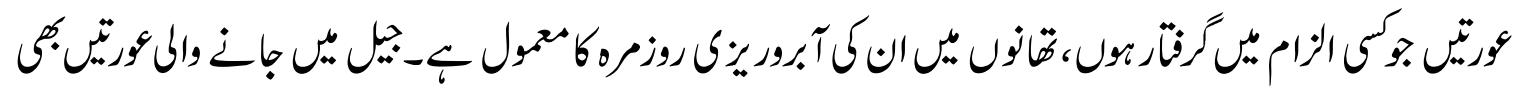

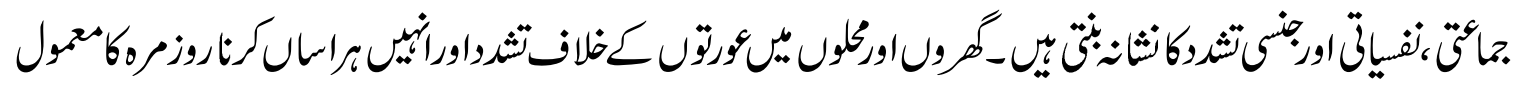

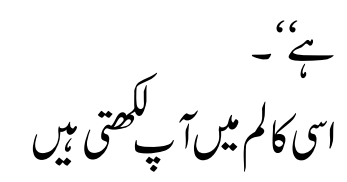

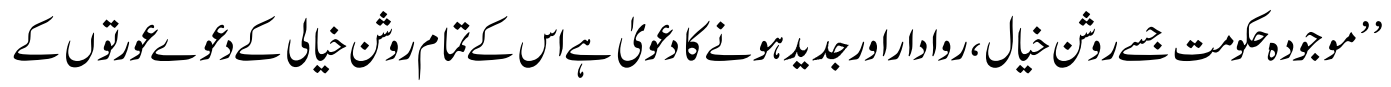

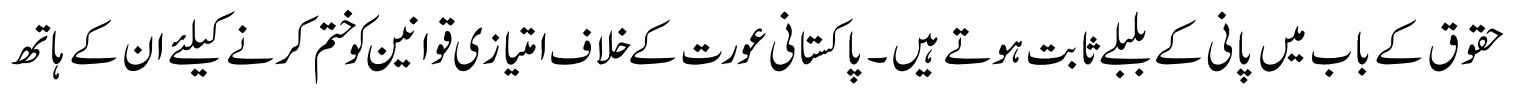

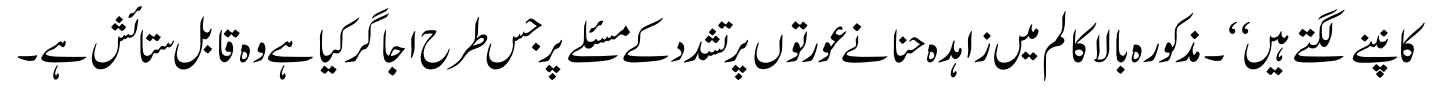

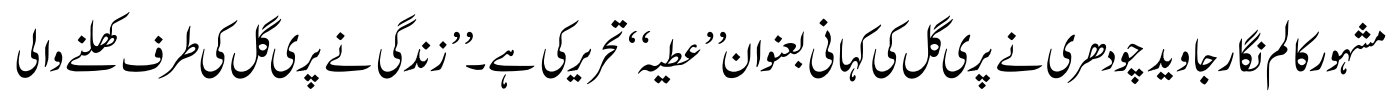

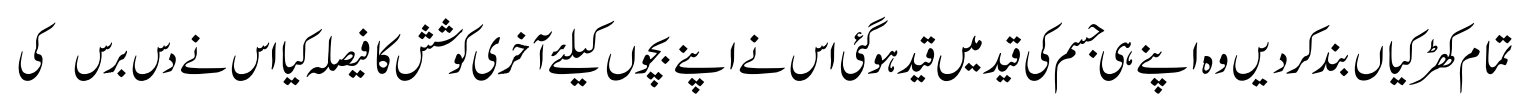




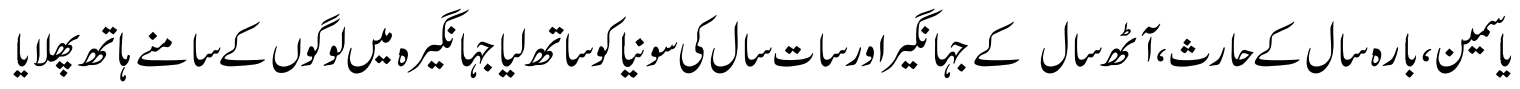

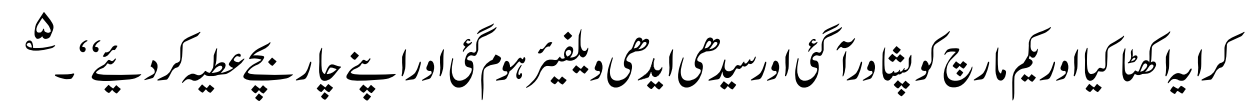

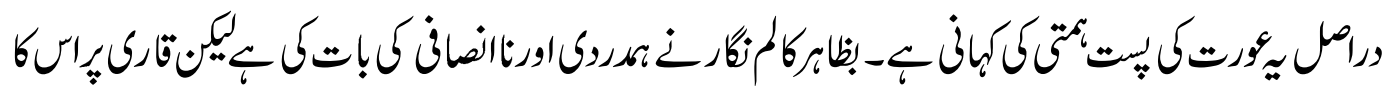

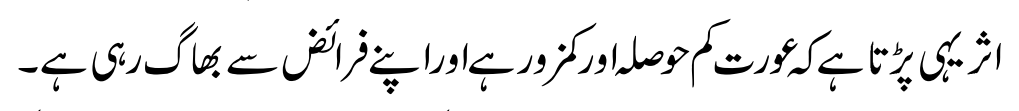

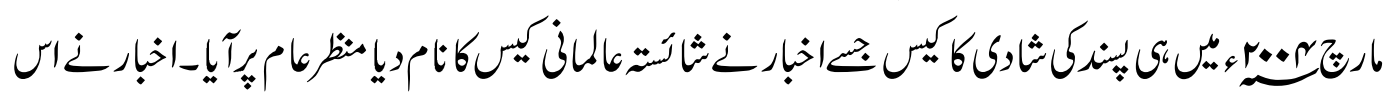

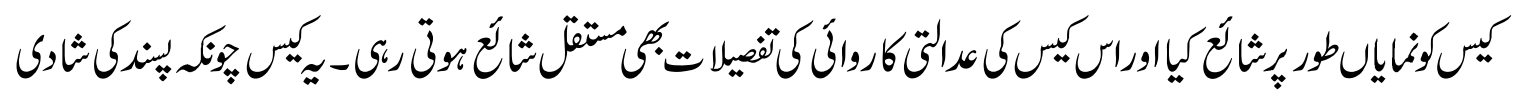

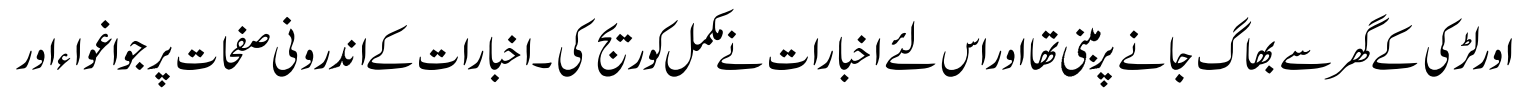

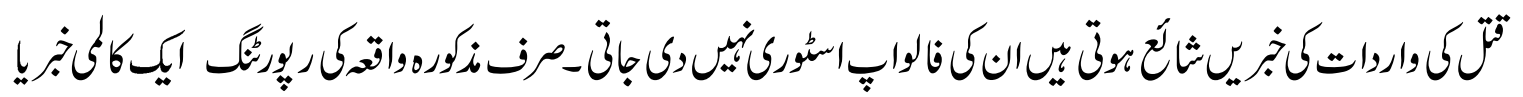

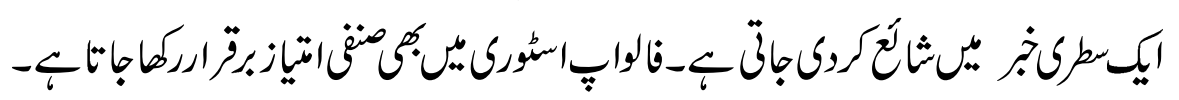

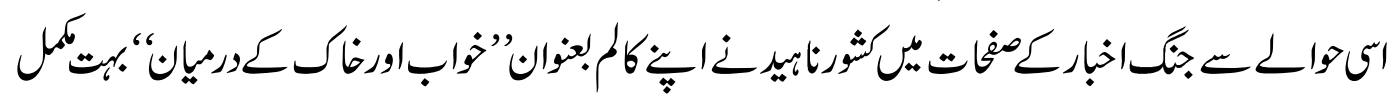

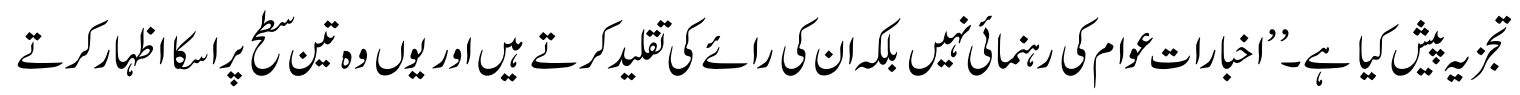

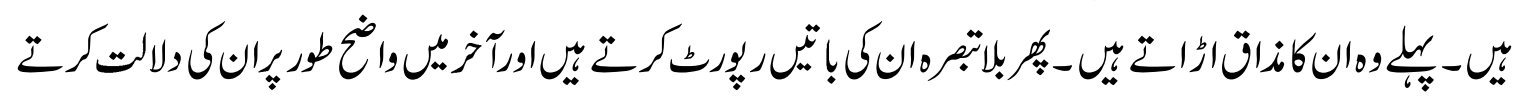

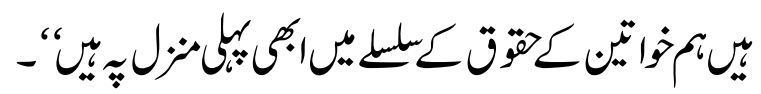

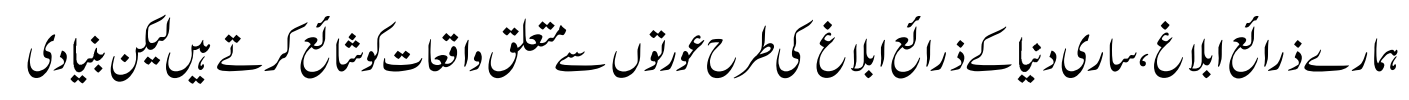

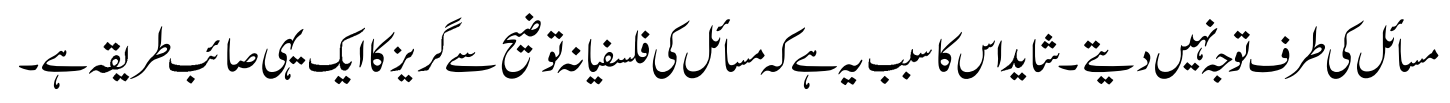

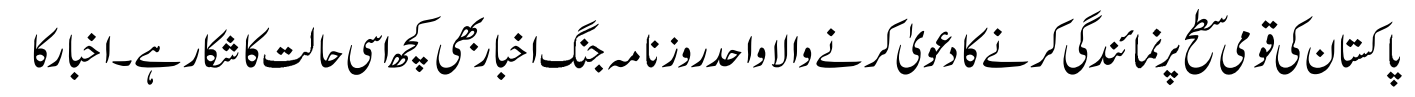

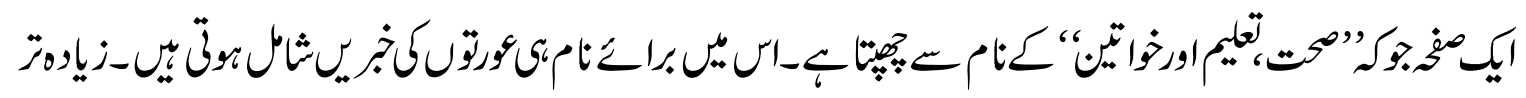

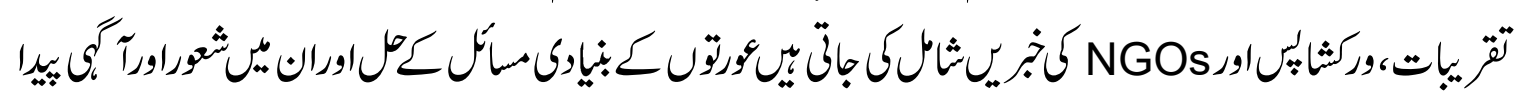

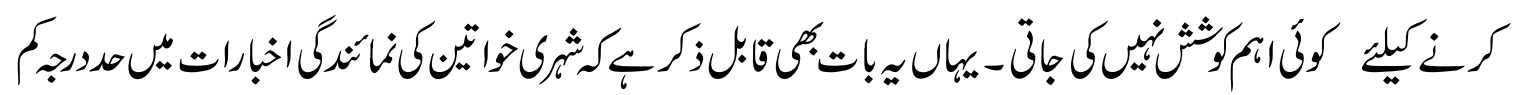

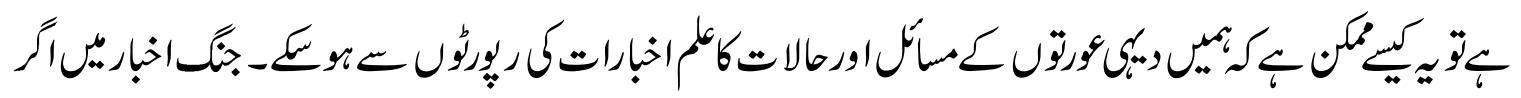

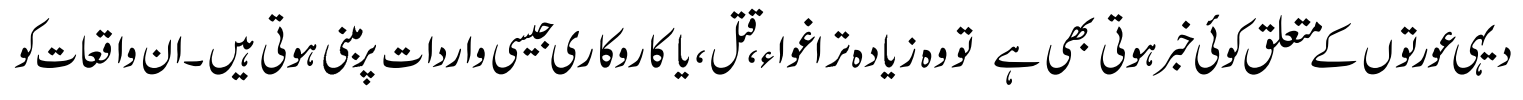




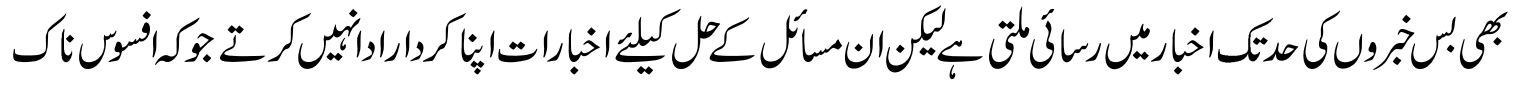

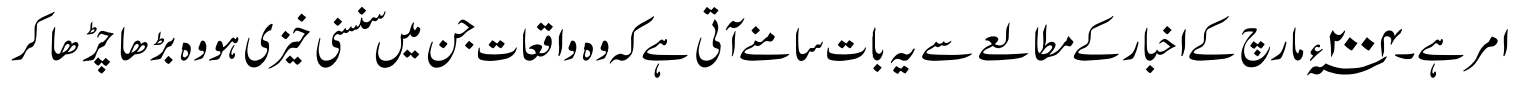

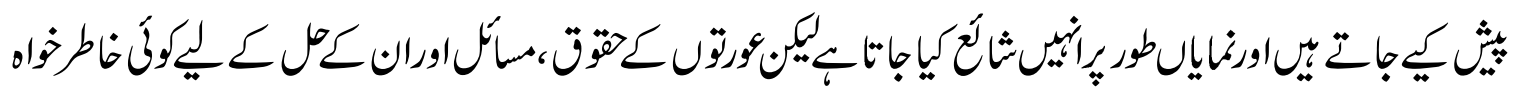

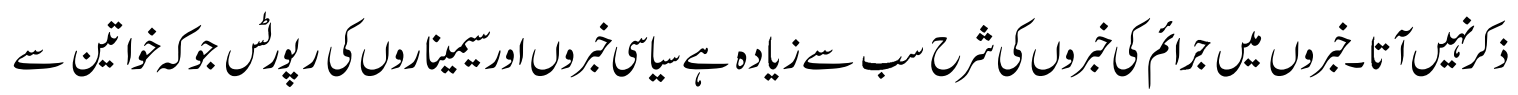

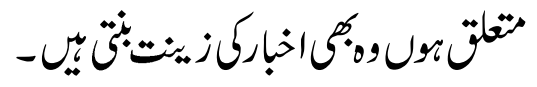

\section{هُ}

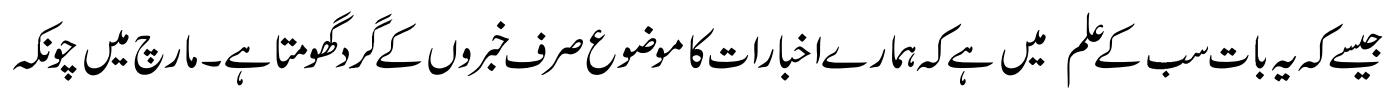

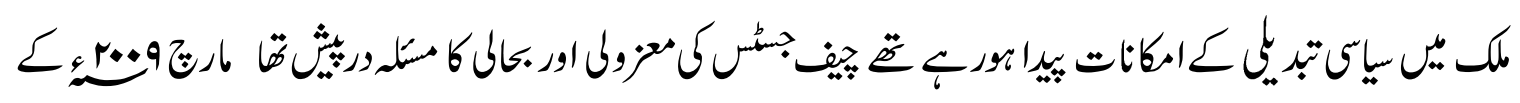

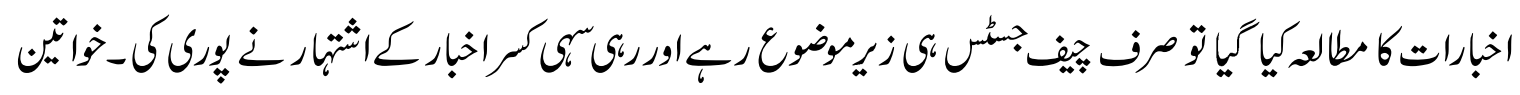

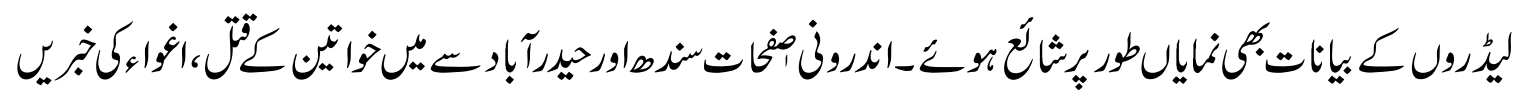

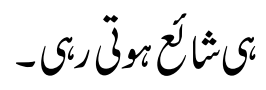

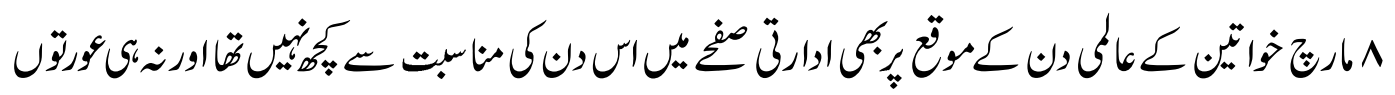

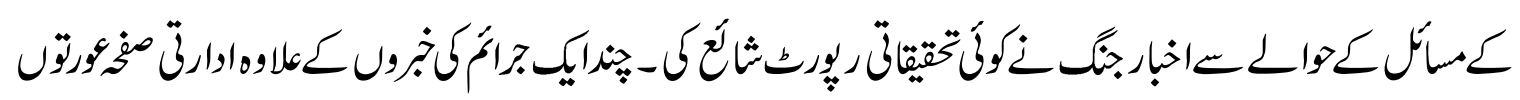

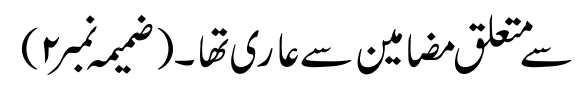

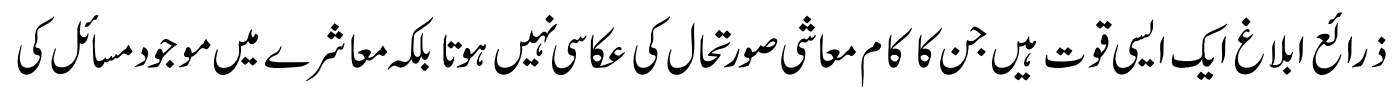

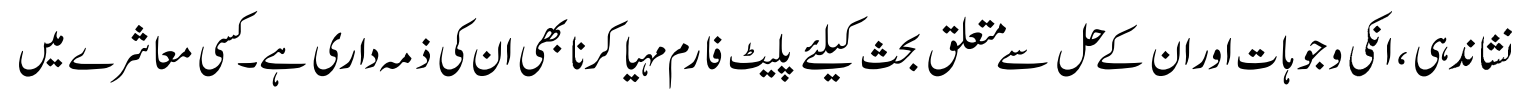

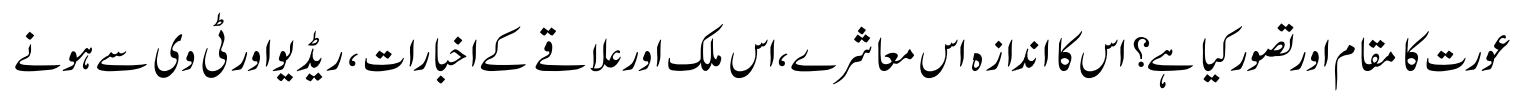

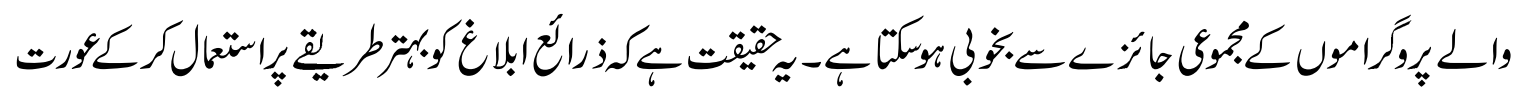

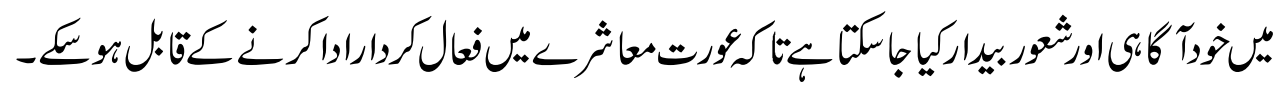

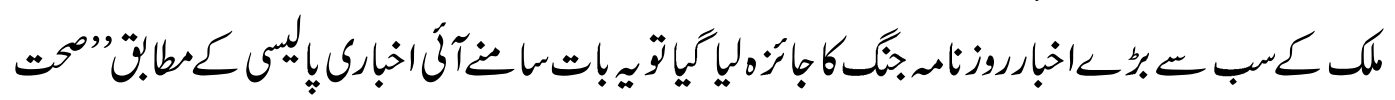

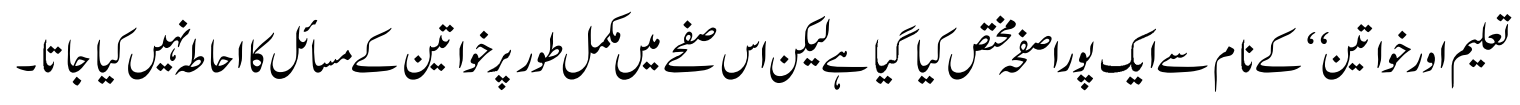




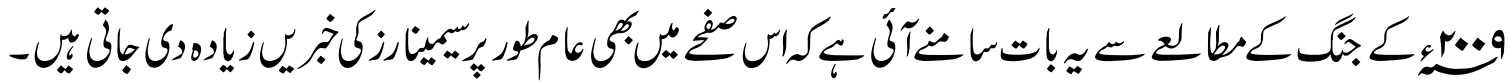

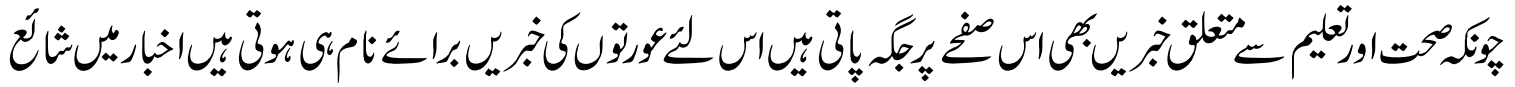

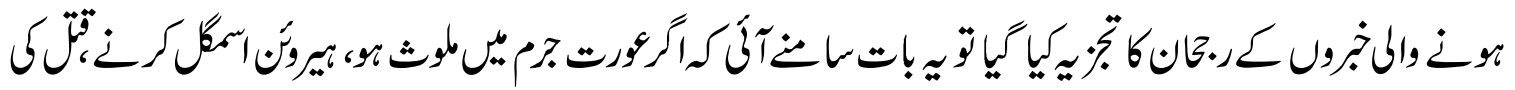

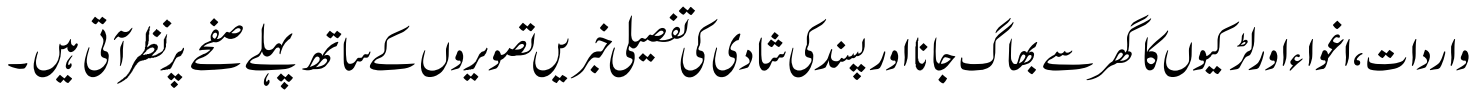

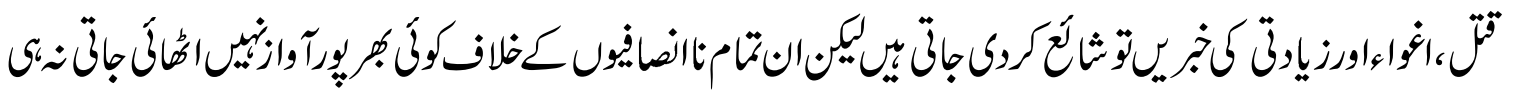

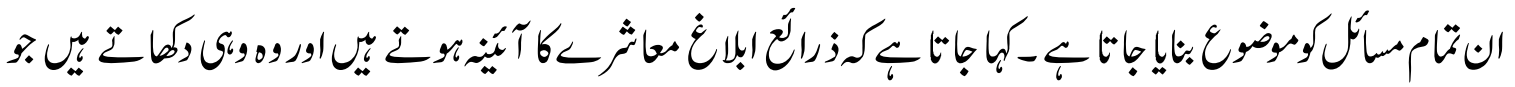

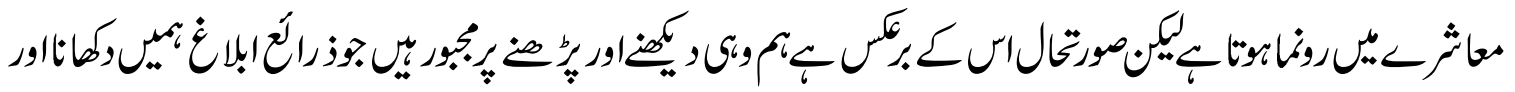
بs

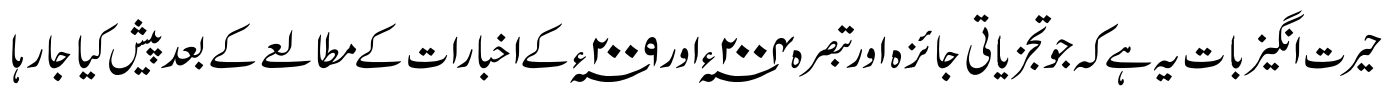

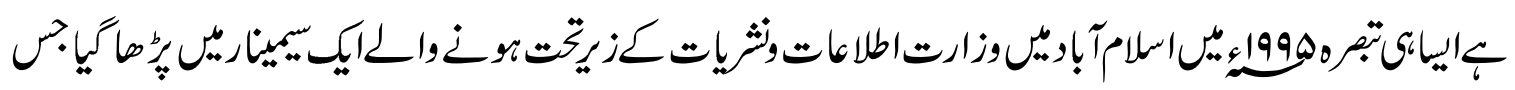

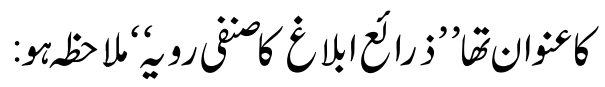

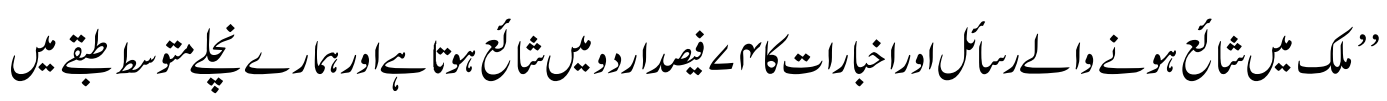

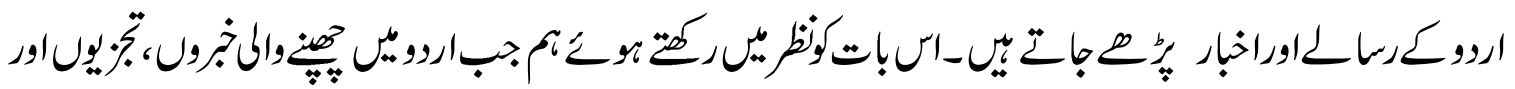

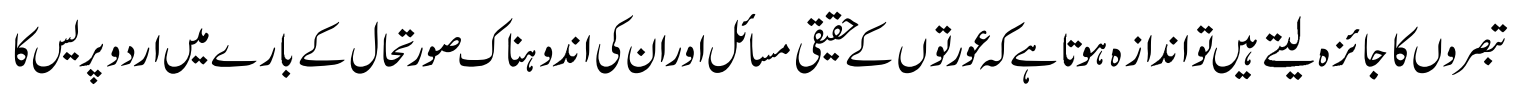

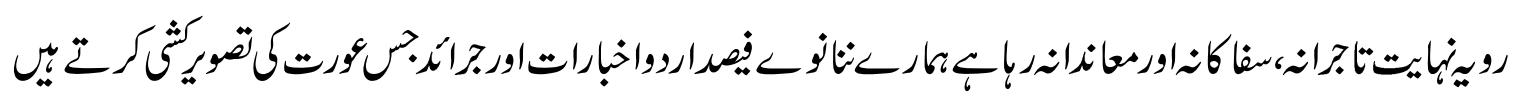

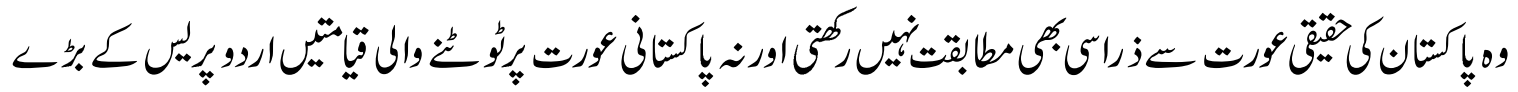

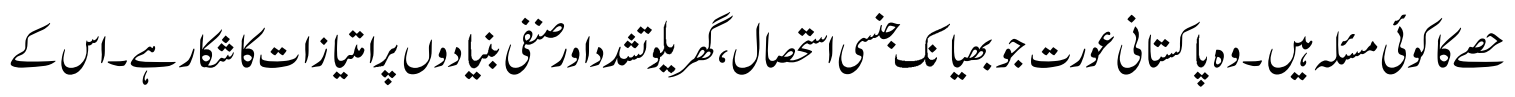

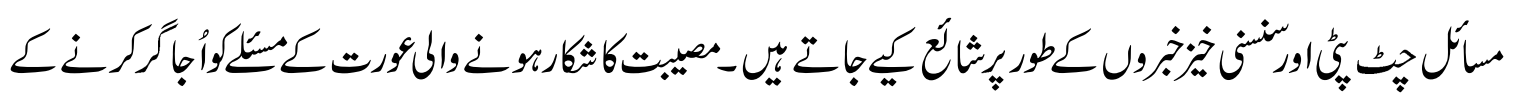

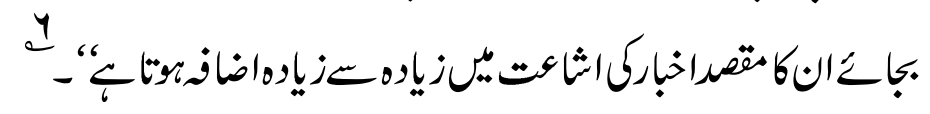

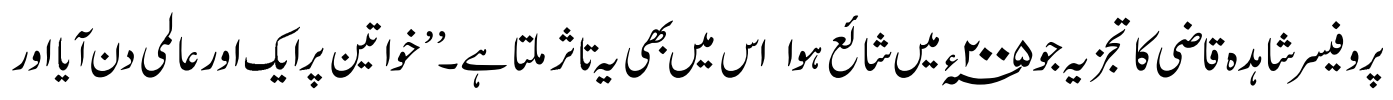




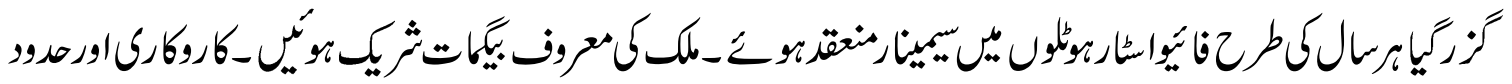

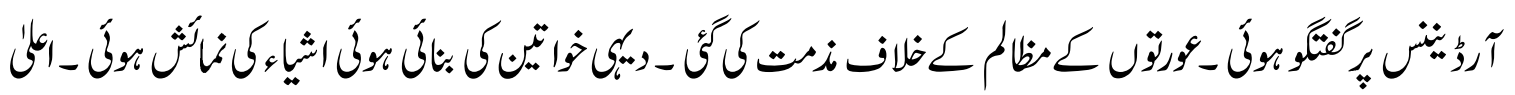

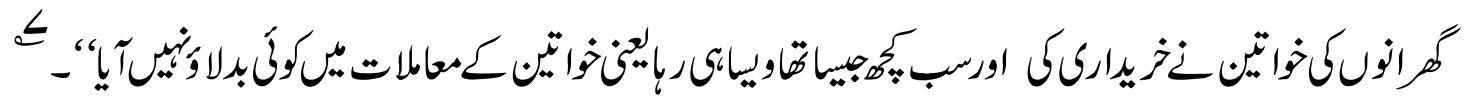

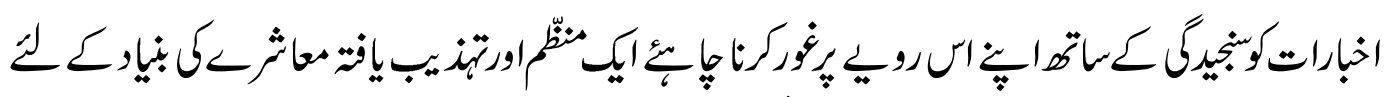

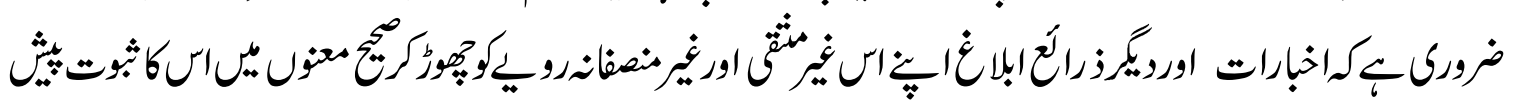

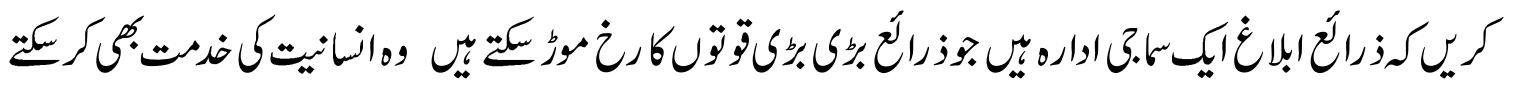

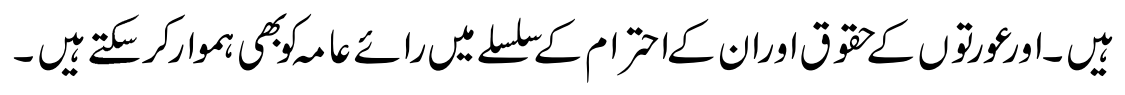

والمجإ

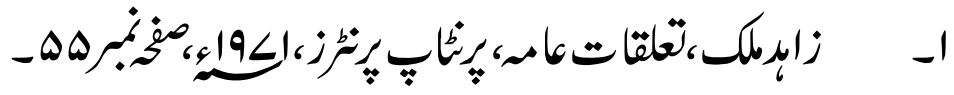

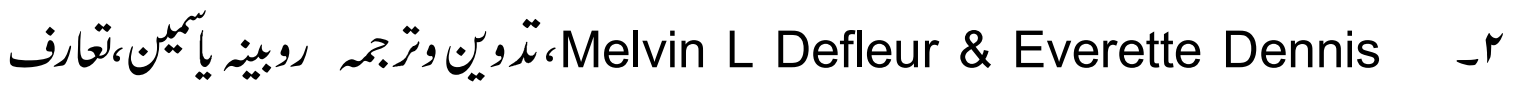

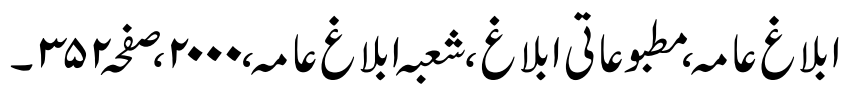

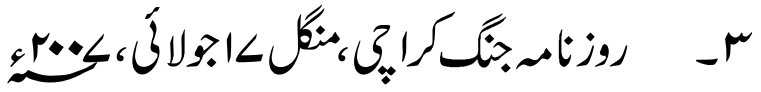

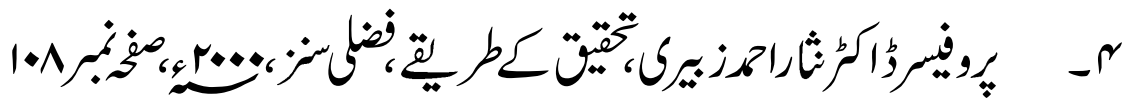

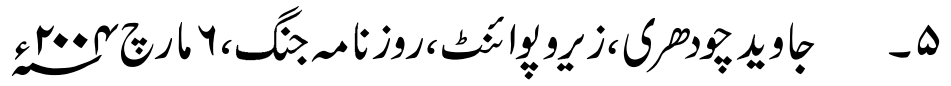

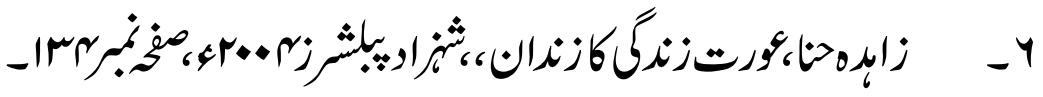

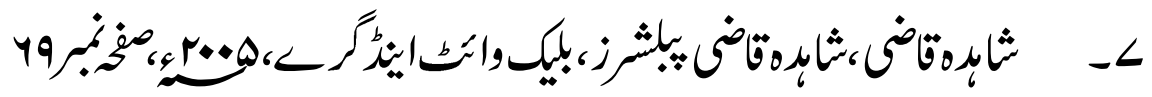

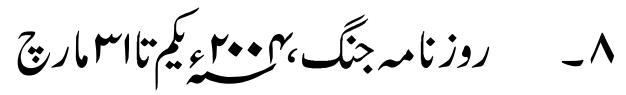

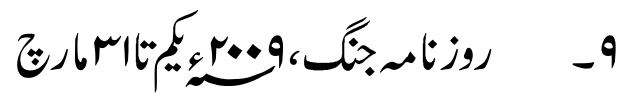




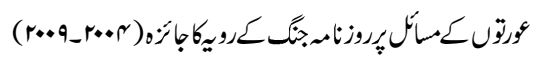

ضممرجم

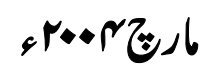

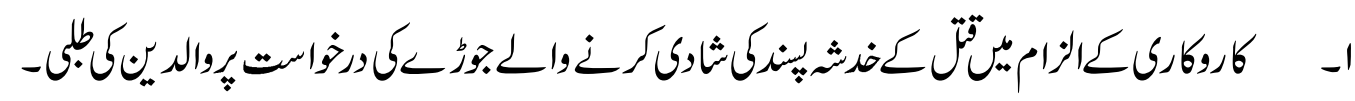

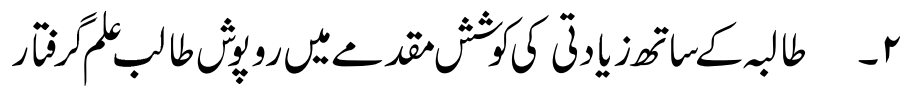

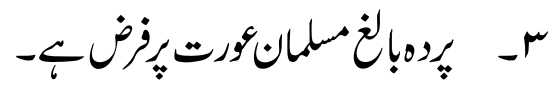

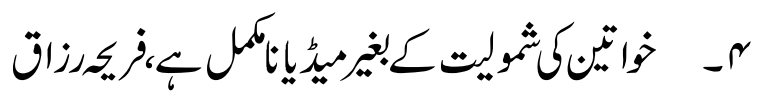

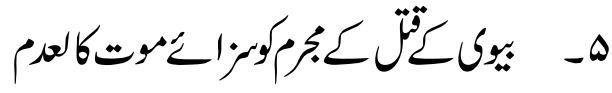

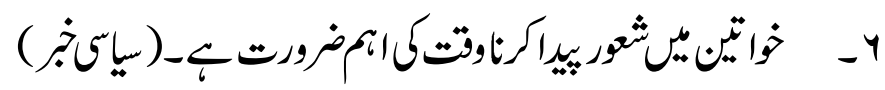

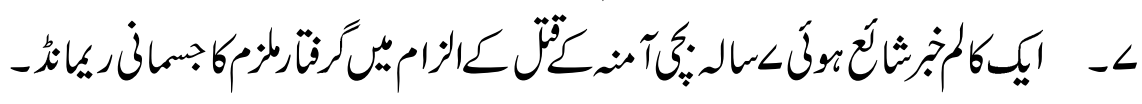
๑r.०9جا

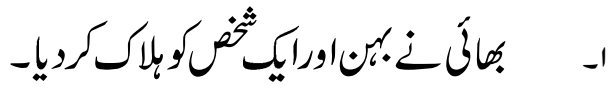

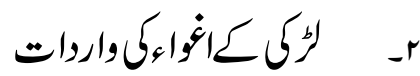

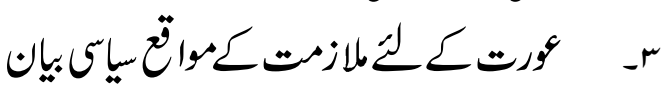

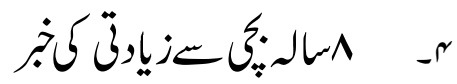

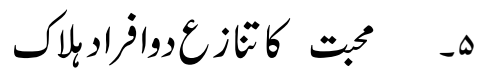

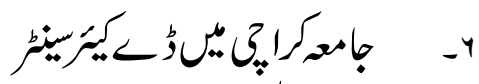

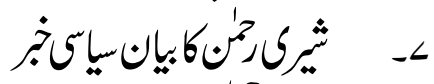

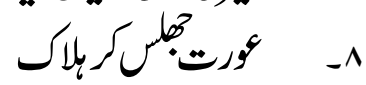

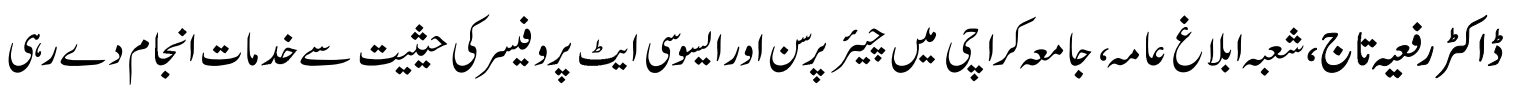

: 